\title{
Larval stages of Chorismus tuberculatus (Decapoda: Caridea: Hippolytidae) from the south-western Atlantic Ocean ${ }^{1}$
}

\author{
Sven Thatje* and Rosa Bacardit ${ }^{\dagger}$ \\ *Alfred Wegener Institute for Polar and Marine Research, PO Box 120 161, D-27515 Bremerhaven, Germany. \\ E-mail: sthatje@awi-bremerhaven.de. †uana Azurduy 1611, 1424 Buenos Aires, Argentina
}

\begin{abstract}
The present work provides a first description of three planktonic larval stages of Chorismus tuberculatus which were obtained from plankton samples collected in the south-western Atlantic during the expeditions of the RVs 'Walther Herwig' and 'Shinkai Maru' in 1978 and 1979, respectively. Three early developmental stages of $C$. tuberculatus are described and compared with those of the second species of this genus, $C$. antarcticus which is known to be distributed in the southern Atlantic Ocean and Antarctica. Both species are distinguishable by the presence/absence of supraorbital spines at the carapace, an anal spine and the exopodite on pereiopod 4. The rostrum is less developed in C. tuberculatus, the shape of the somites is less pronounced, and the number of posterior spines at the telson is lower than in C. antarcticus. Due to an abbreviated larval development as a physiological adaptation to it wider distribution into the Polar region, we assume $C$. antarcticus to have phylogenetically separated from $C$. tuberculatus, represented by the well developed first larval stages in contrast to that of the species described herein.
\end{abstract}

\section{INTRODUCTION}

In order to facilitate future studies on life history strategies, stock-recruitment as well as plankton ecology, we provide the first information about the larval development of the caridean shrimp Chorismus tuberculatus, Bate, 1888. The general knowledge of decapod larval development is scarce, particularly with regard to Chilean and Argentine waters (see Wehrtmann \& Báez, 1997). The description of caridean development is complicated by the variability in larval stages and morphology, thus making it complicated to cultivate larvae in the laboratory (Fincham, 1979; Criales \& Anger, 1986; Villamar \& Brusca, 1988). For this reason, larval descriptions of plankton samples are a first step towards the understanding of organism biology and development.

Two species of the genus Chorismus are known to occur in the south-western Atlantic Ocean (Boschi et al., 1992; Spivak, 1997). Chorismus tuberculatus seems to be restricted in its distribution to the southern Atlantic down to the island of South Georgia (Boschi, 1976, 1979; Boschi et al., 1981), whereas C. antarcticus has been shown to occur in the channels and fjords of the Magellan Region, as well as in the high Antarctic (Retamal, 1981; Arntz \& Gorny, 1991; Gorny et al., 1993; Wehrtmann \& Lardies, 1996). Chorismus antarcticus shows an abbreviated larval development with well developed first zoeae (Gurney, 1937). With respect to this adaptive strategy, due to environmental restrictions in the Antarctic, we compare and discuss our results concerning the larval development of $C$. tuberculatus

${ }^{1}$ this is Alfred Wegener Institute publication no. 1624. in relation to its distribution as well as from a phylogenetic point of view.

\section{MATERIALS AND METHODS}

The present work gives first insights into the larval development of Chorismus tuberculatus Bate. The material studied was collected in Argentine waters in the south-western Atlantic Ocean (Figure 1) during two expeditions carried out on board the RVs 'Walther Herwig' and 'Shinkai Maru' in 1978 and 1979, respectively (Ciechomski et al., 1979; Cousseau, 1979). Samples were collected by means of a plankton net of $330 \mu \mathrm{m}$ mesh size and were preserved in $3 \%$ formalin solution buffered with hexamethylenetetramine. Sampling was performed vertically from the sea-floor to the surface or from $100 \mathrm{~m}$ depth to the surface. Complete descriptions of the cruises and additional information on oceanographic measurements can be obtained from Ciechomski et al. (1979).

Carapace length (CL) was measured from the posterior edge of the orbital arch to the mid-dorsal posterior margin of the carapace; total lengths (TL) of the larvae were measured from the base of the rostrum between the eyes to the distal margin of the telson, excluding setae. Nomenclature used for the differentiation of the larval phases and morphology corresponds to that suggested by Williamson (1960, 1968, 1982), Gurney (1942), Boschi (1981) and Haynes (1978, 1981, 1985).

Larval stages of $C$. tuberculatus have been compared with that of the second species occurring in the area under investigation, C. antarcticus (Gurney, 1937). The eggs and prezoeae of $C$. tuberculatus examined were dissected from preserved egg-carrying females of the INIDEP collection, Buenos Aires, Argentine (Instituto Nacional de Investigación y Desarrollo Pesquero, reg. nos. 1989, 1995). 


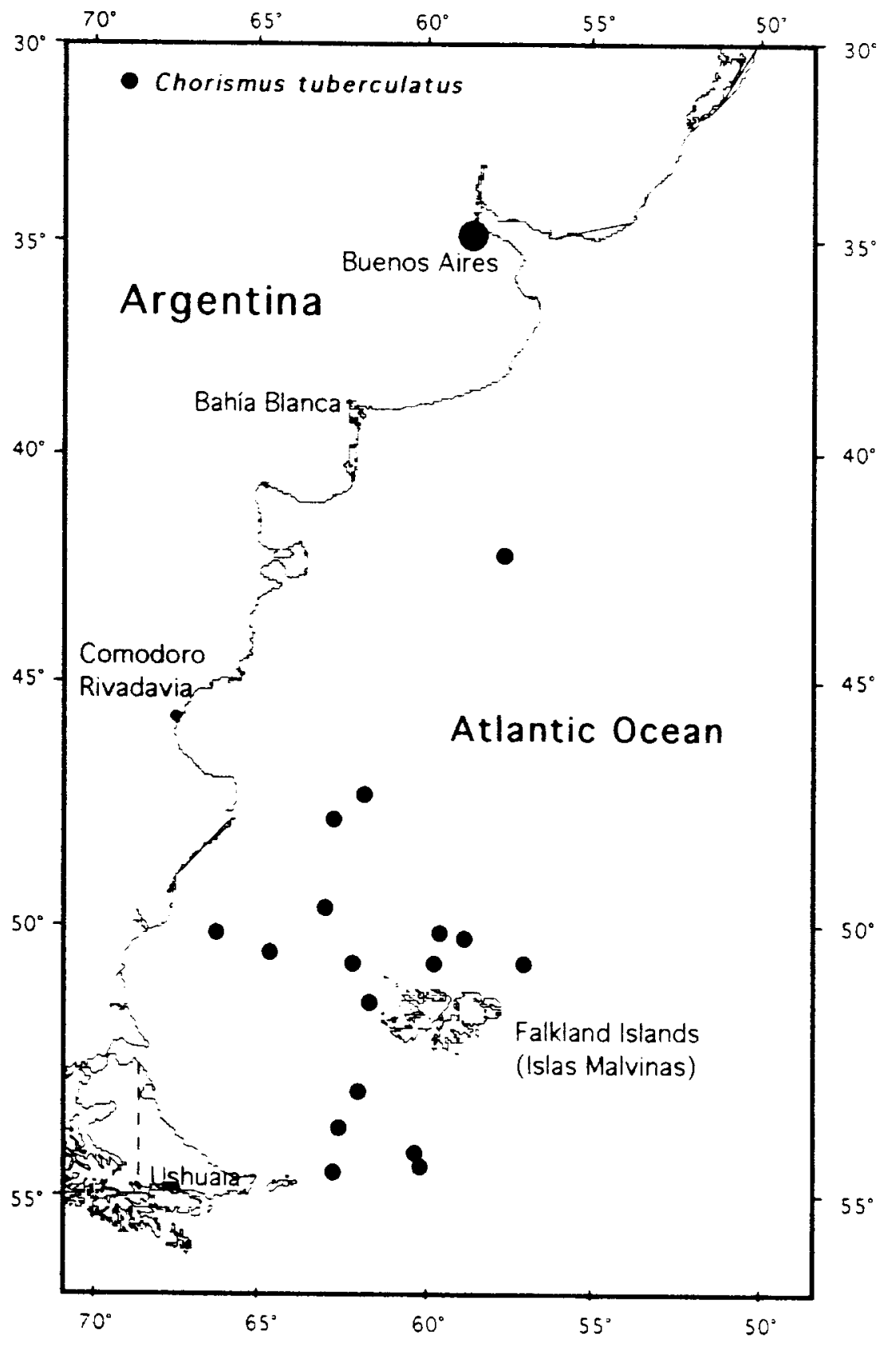

Figure 1. Sampling locations of Chorismus tuberculatus (zoeal stages I-III) in the south-western Atlantic Ocean.

\section{RESULTS}

Family HIPPOLYTIDAE

Chorismus tuberculatus Bate, 1888

Zoea I

(Figures 2A-3K): TL=3.32 $\mathrm{mm}$; CL=0.96 $\mathrm{mm}$.

Carapace (Figure 2A,B): rostrum absent; eyes sessile; carapace with two dorsal protuberances; anterior lateroventral margin with well-developed pterigostomic spine and three anteroventral, stouter spines; carapace dorsally with strong anteriorly directing papillae, and less pronounced posterior one. Antennule (Figure 2D): peduncle unsegmented; external flagellum unsegmented, with three apical aesthetascs, one short seta; internal flagellum represented by one large seta broadened at base. Antenna (Figure 2E): exopod with apical segmenta- tion, with two setae at external margin, internal margin (including tip) bearing ten setae; endopodite with one internal terminal spine, and one shorter external terminal spine; one ventral internal basal spine present. Mandible (Figure $2 \mathrm{~K}$ ): incisor process with sharp small terminal denticles and two strong basal spines, toothed; molar process toothed, prominent. Maxillule (Figure $2 \mathrm{H}$ ): coxal endite with seven setae; basal endite with three strong spines and three setae; palp bisegmented, with three apical and two subterminal setae, no external setae. Maxilla (Figure 2F): coxal endites proximally and distally with seven and four setae, respectively; basal endites with four setae each; palp with indication of four segments with 3,2,1 and 3 proximal and distal setae, respectively; scaphognathite with five apical setae. Maxilliped 1 (Figure 2G): coxa with 1, 1, 2, 1 and 2 proximal and distal setae, respectively; base with 1, 1, 3, 3, and 3 


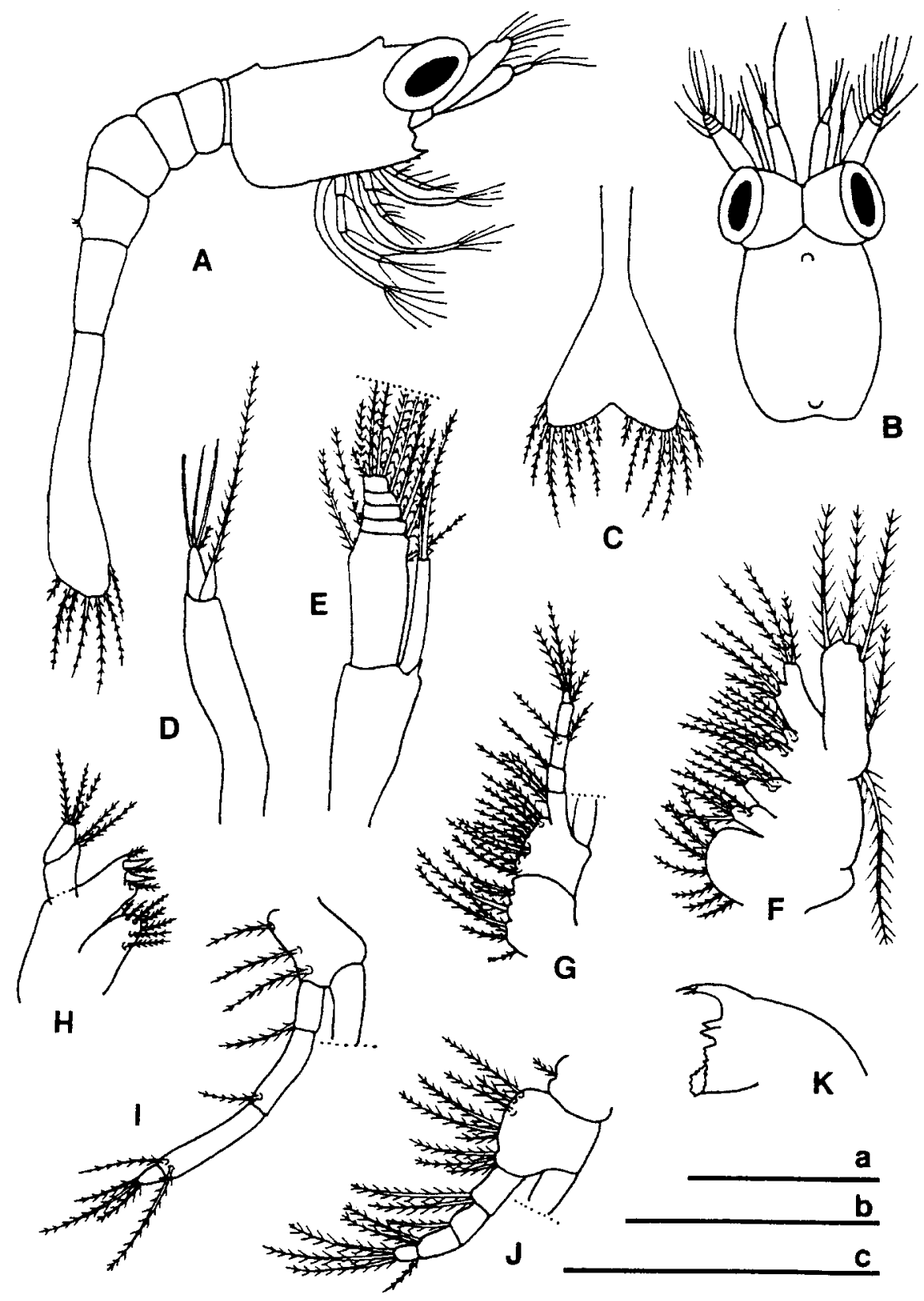

Figure 2. Zoea I of Chorismus tuberculatus: (A) general aspect, lateral view; (B) carapace with cephalic appendages, dorsal view; $(\mathrm{C})$ telson, ventral view; (D) antennule; (E) antenna; (F) maxilla; $(\mathrm{G})$ maxilliped 1; $(\mathrm{H})$ maxillule 1; (I) maxilliped 3; (J) maxilliped 2; (K) mandible. Scale bars: (a) F, H, K, $0.2 \mathrm{~mm}$; (b) A-C, $1 \mathrm{~mm}$; (c) D, E, G, I, J, $0.5 \mathrm{~mm}$.

proximal and distal setae, respectively; endopodite of five segments with 3,1,2, and 4 proximal and distal setae, respectively; exopodite with three apical setae and one subterminal one. Maxilliped 2 (Figure 2J): coxa with one seta; base with 1,2, 3 and 3 proximal and distal setae, respectively; endopodite of four segments with 2, 1, 2 and 4 proximal and distal setae, respectively; exopodite with three terminal and two subterminal setae. Maxilliped 3 (Figure 2I): base with three setae; endopodite of four segments with 1, 1, 2 and 3 proximal and distal setae, respectively; exopodite with three terminal and two subterminal setae. Pereiopods: reduced. Abdomen (Figure 2A): somites $1-5$ the same, without marginal ornamentations; somite 4 bearing a small dorsal protuberance and three small setae; somite 6 continuous with telson. Telson (Figure 2A \& $\mathrm{G}$ ): triangular posterior margin, with strong median indentation; posterior margin with $7+7$ setulose setae.

\section{Zoea II}

(Figure $3 \mathrm{~A}-\mathrm{F}$ ): $\mathrm{TL}=3.74 \mathrm{~mm} ; \mathrm{CL}=0.98 \mathrm{~mm}$.

Carapace (Figure 3A \& G): cephalic appendages with pair of prominent, lateral orientated pedunculate eyes; rostrum present, triangulate, broadened at base and produced; margins as in previous stage. Antennule (Figure $3 \mathrm{E})$ : peduncle partially divided into two segments; distal segment with one external spine and one external prolongation by one large seta (internal flagellum); external flagellum unsegmented, with four aesthetascs and one seta. Antenna (Figure 3F): exopodite with incomplete apical segmentation; two marginal external setae; internal 

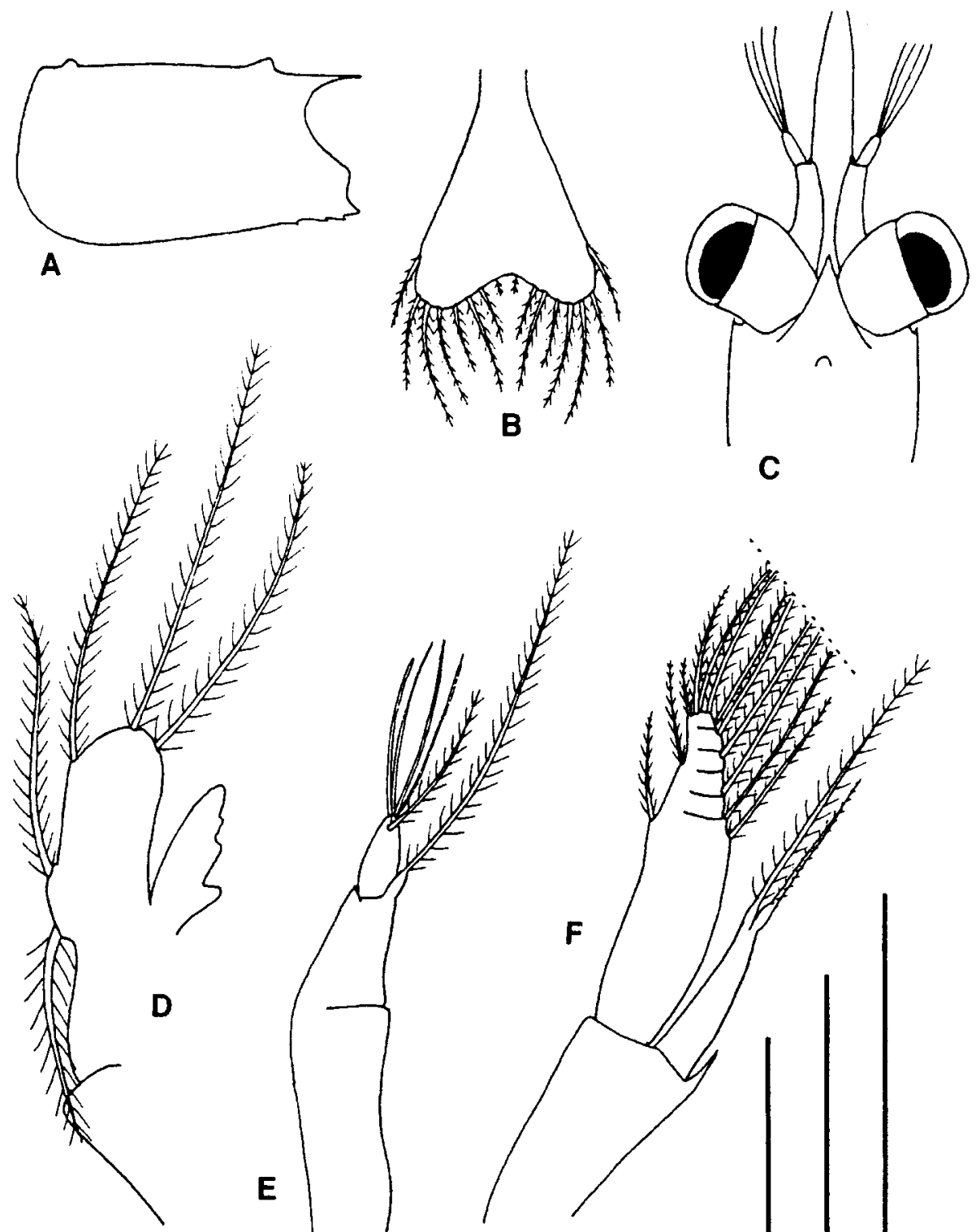

B

C

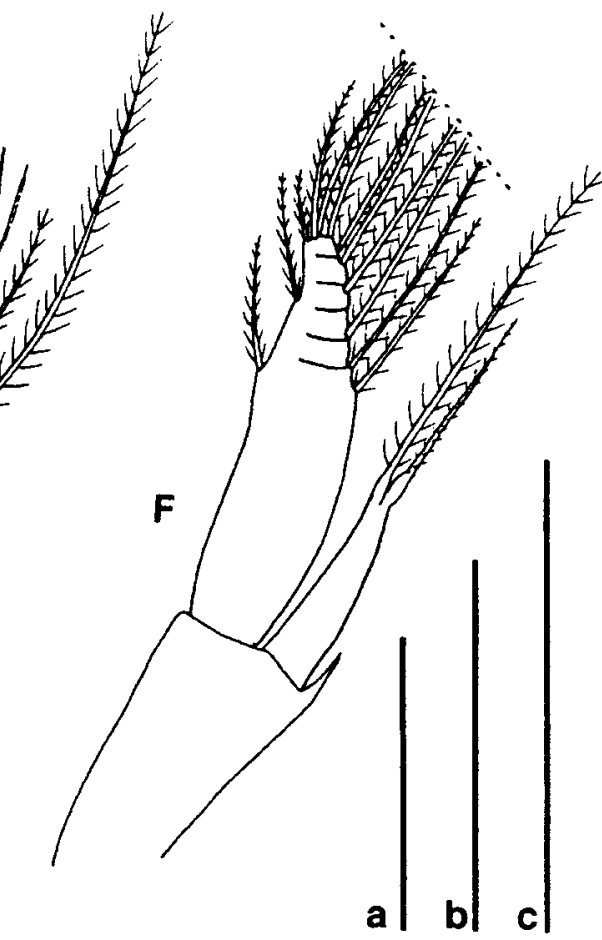

Figure 3. Zoea II of Chorismus tuberculatus: (A) carapace, lateral view; (B) telson, ventral view; (C) cephalon, dorsal view; (D) maxilla, detail of scaphognathite, seate of palp omitted; (E) antennule; (F) antenna. Scale bars: (a) D, $0.2 \mathrm{~mm}$ (b) A-C, $1 \mathrm{~mm}$; (c) E, F, $0.5 \mathrm{~mm}$.

margin (including tip) with ten setae; external seta of endopodite larger as internal spine; no other differences. Maxillule: coxal endite with seven setae; basal endite with six spines and one seta; no other differences. Maxilla (Figure 3D): coxal endites proximally and distally with 12 and four setae, respectively; basal endites with five setae each; scaphognathite with five plumose setae. Maxilliped 1: coxa and base as in zoea I; exopodite with four apical and one subterminal setae; no other differences. Maxilliped 2: endopodite of five segments; carpus without setae; exopodite with eight plumose setae; no other differences. Maxilliped 3: endopodite of five segments; carpus without setae; exopodite with eight plumose apical setae. Pereiopods: reduced, biramous; fifth pair uniramous. Abdomen: dorsal protuberance at somite four absent; no other differences. Telson (Figure 3B): posterior margin with $8+8$ setulose setae, central pair reduced.
Zoea III

(Figure $4 \mathrm{~A}-\mathrm{J}$ ): $\mathrm{TL}=4.2 \mathrm{~mm} ; \mathrm{CL}=1 \mathrm{~mm}$.

Carapace (Figure 4A,B): proportionally more extended, prominent as in previous stage; rostrum more broadened at base, stouter; dorsal anterior protuberances curved; no other differences. Antennule (Figure 4E): peduncle bisegmented, more pronounced as in previous stage; basal segment slightly concave at external margin; distal segment bearing one large seta; distal medial lobe less pronounced, with six setae; internal flagellum represented by small protuberance and large distal seta; external flagellum with three aesthetascs and one seta. Antenna (Figure 4D): exopodite with two marginal external setae, without external spines; internal margin (including tip) with 12 setae; exopodite with one terminal spine, much shorter than exopodite; no other differences. 


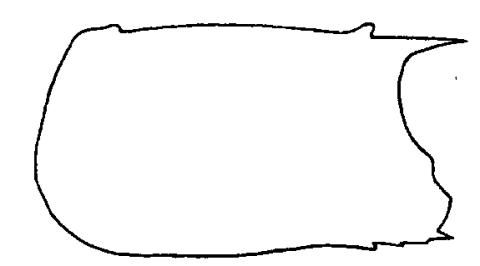

A
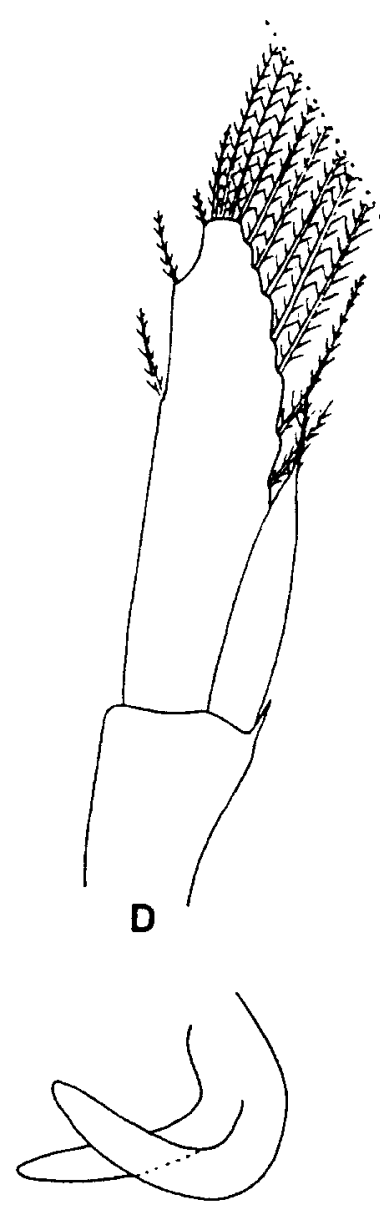

G

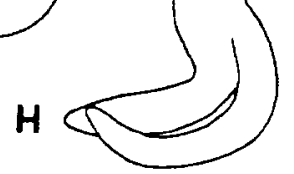

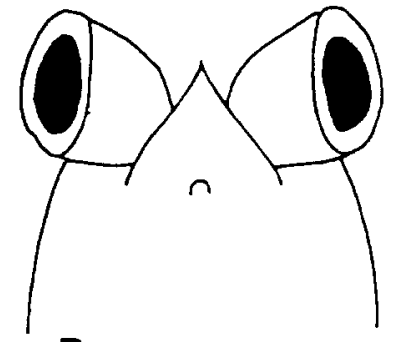

B

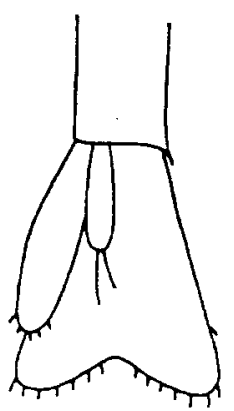

C

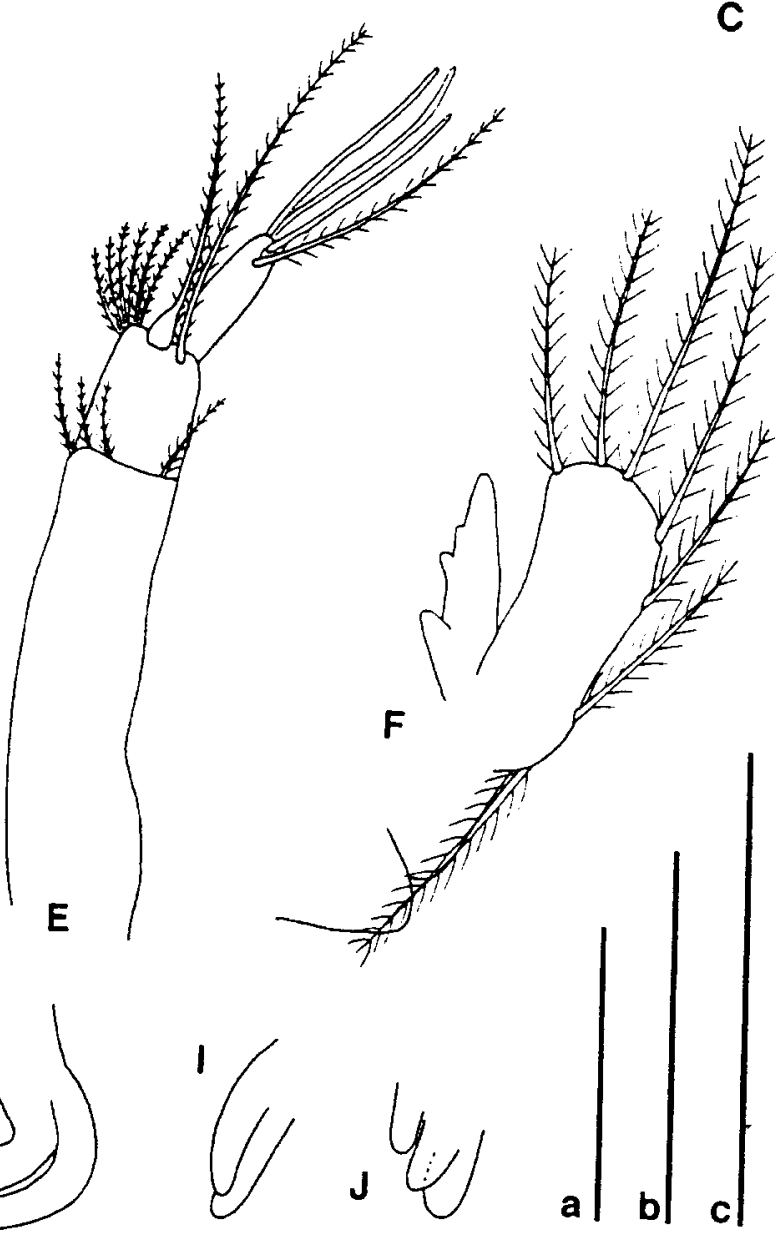

Figure 4. Zoea III of Chorismus tuberculatus: (A) carapace, lateral view, (B) cephalon, dorsal view; (C) uropods and telson, ventral view; (D) antenna; (E) antennule; (F) maxilla 2, detail of scaphognathite, setae of palp omitted; (G) pereiopod 1, lateral view; $(\mathrm{H})$ pereiopod 2, lateral view; (I) pereiopod 3, lateral view; (J) pereiopods 4 and 5, lateral view. Scale bars: (a) F, 0.2 mm; (b) A-C, $1 \mathrm{~mm}$; (c) D, E, G-J, $0.5 \mathrm{~mm}$.

Mandible: without palp; no other differences. Maxillule: coxal endite with seven setae; basal endite with eight spines; no other differences. Maxilla (Figure 4F): coxal endites proximally and distally with 12 and four setae, respectively; basal endites with six setae each; scaphognathite with seven marginal setae. Maxilliped 1-3: no changes with respect to previous stage. Pereiopods 1-4 (Figure $4 \mathrm{G}-\mathrm{J}$ ): biramous, with no separation between basis endo- and exopodite; all without segmentation and setae. Pereiopod 5 (Figure 4J): uniramous, reduced; represented by a small lobe. Abdomen: somite six free (Figure 4C), with well developed posteriorlateral spines, without pleopods; no other differences. Uropods (Figure 4C): endouropod with two apical setae; exouropod without external spine, bearing five marginal setae.
Telson (Figure 4C): stouter as in previous stages; posterior margin with $8+8$ short setulose setae.

\section{Observations}

Eggs of C. tuberculatus showed a mean length of $1.2 \mathrm{~mm}$ and width of $0.9 \mathrm{~mm}$; prezoea, $\mathrm{TL}=3.2 \mathrm{~mm}$. The eggs are much smaller than those of $C$. antarcticus in length $(1.7 \mathrm{~mm})$ and width (1.3 mm; compare with Gurney, 1937). Eggs of $C$. antarcticus are yolk-rich, whereas yolk is scant in those of C. tuberculatus. Prezoeae of C. antarcticus bear developed pereiopods which are absent in C. tuberculatus.

\section{DISCUSSION}

The larval development of Chorismus antarcticus is well known by the work of Gurney (1937). Larvae of both 
Chorismus species show similar morphological features, thus are comparable in certain aspects. Distinctive characteristics of larvae of C. antarcticus (after Gurney, 1937) are: (1) rostrum large and robust, well-developed; (2) carapace with supraorbital spines, with smooth margins; (3) telson broad, posterior margin with 20 spines (zoea I); (4) anal spine present; (5) antennal exopodite with segmentation, bearing an external seta; endopodite presented by a large flagellum (zoea I); (6) exopodite of maxilliped 3 with three apical setae in zoea I; (7) pereiopods 1-3 with exopodite; (8) abbreviated larval development.

The herein described larvae of $C$. tuberculatus show certain differences in comparison to $C$. antarcticus: (1) rostrum short, less developed; (2) carapace without supraorbital spines; anteroventral margin with three spines; (3) telson with $7+7$ processes at posterior margin in zoea I; (4) anal spine absent in zoeal stages I-III; (5) endopodite of antennule with 1 spine and 1 terminal seta in zoea I; (6) exopodite of maxilliped 3 without apical setae in zoea I; (7) pereiopods $1-4$ with exopodite; (8) extended larval development.

Morphological differences between larvae of both species seem to result from the type of larval development. In the present work we were only able to describe the three first larval stages of $C$. tuberculatus, because more advanced larvae did not occur in our samples. On the other hand certain larval features occur which clearly point out the differences between both species and support the view of an extended larval development of C. tuberculatus: (i) in many genera the increase in the number of pereiopods bearing exopods in early zoeae, correlates with a reduction in larval stages as a principal evolutionary tendency towards an abbreviated development (Pike \& Williamson, 1964); (ii) supraorbital spines of the carapace get more pronounced in advanced stages, and marginal denticles reduce; (iii) the presence of many posterior processes at the telson of first larvae is characteristic of an abbreviated development; (iv) in many genera with extended larval development, an anal spine appears after the fourth or fifth zoeal stage; (v) the additional apical setae of the endopodite of the antenna is reduced in the first stages (until third or fourth); (vi) eggs are small-sized in extended larval development.

Chorismus tuberculatus is known to occur at the continental slope and in the coastal waters of the southwestern Atlantic Ocean, mainly in Argentine waters (Boschi, 1976, 1979; Boschi et al., 1981), whereas C. antarcticus is distributed from the channels and fjords of the Magellan Region (Beagle Channel) south to the high Antarctic Weddell Sea (Retamal, 1981; Arntz \& Gorny, 1991; Gorny et al., 1993; Wehrtmann \& Lardies, 1996). A phylogenetic separation of C. antarcticus from C. tuberculatus and a later adaptation to the Antarctic is shown by its abbreviated development, as well as due to other physiological adaptations, such as slower growth and lower mortality (Gorny et al., 1993). Gorny et al. (1993) and Maxwell (1977) also mentioned differences between the populations of $C$. antarcticus from the Weddell Sea and South Georgia which, in addition, is the southernmost occurrence of C. tuberculatus. They showed the population around South Georgia to produce smaller eggs and to differ in size at maturity which is, also with respect to the larval development of $C$. tuberculatus, a hint at a latitudinal adaptation to changing environmental parameters.

Although many decapod species with an abbreviated larval cycle are known to occur in the south-western Atlantic, such as C. antarcticus, Campylonotus sp., Paralomis granulosa, Pandalopsis ampla (Boschi et al., 1992; Spivak, 1997; Thatje et al., in press), larvae of these species were never obtained from our plankton samples or are extremely rare. Probably, these big-sized larvae mainly live close to the sea-floor as demersal drifters, thus sampling by vertical hauls which were mainly carried out in the free-water column, did not allow sampling of these larval types.

We are indebted to Ingo Wehrtmann for his critical and helpful comments on the manuscript. The first author is grateful to the International Bureau of the German Ministry of Research (BMBF) and to Wolf Arntz and Dieter Gerdes for supporting his scientific work in South America.

\section{REFERENCES}

Arntz, W.E. \& Gorny, M., 1991. Shrimp (Decapoda: Natantia) occurrence and distribution in the eastern Weddell Sea, Antarctica. Polar Biology, 11, 169-177.

Boschi, E.E., 1976. Nuevos aportes al conocimiento de la distribución geográfica de los Crustáceos Decápodos del Mar Argentino. Physis (Buenos Aires), 35, 59-68.

Boschi, E.E., 1979. Geographic distribution in Argentinean marine Decapoda crustaceans. Bulletin of the Biological Society Washington, 3, 134-143.

Boschi, E.E., 1981. Larvas de Crustacea Decapoda. In Atlas de zooplancton del Atlántico Sudoccidental y métodos de trabajo con el zooplancton marino (ed. D. Boltovskoy), pp. 699-718. Mar del Plata, Argentina: Instituto Nacional de Investigación y Desarrollo Pesquero.

Boschi, E.E., Fischbach, C.E. \& Iorio, M.I., 1992. Catálogo ilustrado de los crustáceos estomatópodos y decápodos marinos de Argentina. Frente Maritima, 10, 7-94.

Boschi, E.E., Iorio, M.I. \& Fischbach., K., 1981. Distribución y abundancia de los crustáceos decápodos capturadas en las campañas de los B/I 'Walther Herwig' y 'Shinkai Maru' en el Mar Argentino, 1978-1979. Instituto Nacional de Investigación y Desarrollo Pesquero, Mar del Plata, 383, 231-253.

Ciechomski, J.D., Ehrlich, M.D., Lasta, C.A. \& Sanchez, R.P., 1979. Campañas realizadas por el buque de investigación 'Walther Herwiǵ en el Mar Argentino, desde mayo hasta noviembre 1978. Organización y reseña de datos básicos obtenidos. Instituto Nacional de Investigación y Desarrollo Pesquero, Mar del Plata, 374, 1-311.

Cousseau, M.B., Hansen, J.E. \& Gru, D., 1979. Campañas realizado por el buque de investigación 'Shinkai Maru' en el Mar Argentino, desde abril de 1978 hasta abril de 1979. Organización y reseña de datos obtenidos. Instituto Nacional de Investigación y Desarrollo Pesquero, Mar del Plata, 373, 1-625.

Criales, M.M. \& Anger, K., 1986. Experimental studies on the larval development of the shrimps Crangon crangon and C. allmanni. Helgoländer Meeresuntersuchungen, 40, 241-265.

Fincham, A.A., 1979. Larval development of British prawns and shrimps (Crustacea: Decapoda: Natantia). 3. Palaemon (Palaemon) longirostris H. Milne Edwards, 1837 and the effect of antibiotic on morphogenesis. Bulletin of the British Museum (Natural History) (Zoology), 37, 17-46. 
Gorny, M., Brey, T., Arntz, W.E. \& Bruns, T., 1993. Growth, development and productivity of Chorismus antarcticus (Pfeffer) (Crustacea: Decapoda: Natantia) in the eastern Weddell Sea, Antarctica. Fournal of Experimental Marine Biology and Ecology, 174, 261-275.

Gurney, R., 1937. Larvae of decapod Crustacea. Part IV. Hippolytidae. Discovery Reports, 14, 351-404.

Gurney, R., 1942. Larvae of decapod Crustacea. London: The Ray Society.

Haynes, E.B., 1978. Description of larvae of a hippolytid shrimp, Lebbeus groenlandicus, reared in situ in Kachemay Bay, Alaska. Fishery Bulletin. National Oceanic and Atmospheric Administration. Washington, DC, 76, 457-465.

Haynes, E.B., 1981. Early zoeal stages of Lebbeus polaris, Eualus suckleyi, E. fabricii, Spirontocaris arcuata, S. achotensis and Heptacarpus camtschatiens (Crustacea, Decapoda, Caridea, Hippolytidae) and morphological characterization of zoea Spirontocaris and related genera. Fishery Bulletin. National Oceanic and Atmospheric Administration. Washington, DC, 79, 421-440.

Haynes, E.B., 1985. Morphological development, identification, and biology of larvae of Pandalidae, Hippolytidae, and Crangonidae (Crustacea, Decapoda) of the northern north Pacific Ocean. Fishery Bulletin. National Oceanic and Atmospheric Administration. Washington, $D C, \mathbf{8 0}, 501-521$.

Maxwell, J.G.H., 1977. The breeding biology of Chorismus antarcticus (Pfeffer) and Notocrangon antarcticus (Pfeffer) (Crustacea, Decapoda) and its bearing on the problems of an impoverished Antarctic decapod fauna. In Adaptations within Antarctic ecosystems (ed. G. Llano), pp. 335-342. Houston, Texas: Gulf Publication.
Pike, R.B. \& Williamson, D.I., 1964. The larvae of some species of Pandalidae (Decapoda). Crustaceana, 6, 265-284.

Retamal, M.A., 1981. Catálogo ilustrado de los crustáceos decápodos de Chile. Gayana, Zoología, 44, 1-110.

Spivak, E.D., 1997. Los crustáceos decápodos del Atlántico sudoccidental $\left(25^{\circ}-55^{\circ} \mathrm{S}\right)$ : distribución y ciclos de vida. Investigaciones Marinas, Valparaíso, 25, 73-92.

Thatje, S., Bacardit, R., Romero, M.C., Tapella, F. \& Lovrich, G.A., in press. Description and key to the zoeal stages of the Campylonotidae (Decapoda, Caridea) from the Magellan Region. Fournal of Crustacean Biology.

Villamar, D.F. \& Brusca, G.J., 1988. Variation in the larval development of Crangon nigricauda (Decapoda: Caridea), with notes on larval morphology and behaviour. Fournal of Crustacean Biology, 8, 410-419.

Wehrtmann, I.S. \& Lardies, M.A., 1996. Species composition and geographical distribution of caridean shrimps (Decapoda: Caridea). In Cruise report on the Foint Chilean-German-Italian Magellan 'Victor Hensen' Campaign in 1994 (ed. W.E. Arntz and M. Gorny). Berichte zur Polarforschung, 190, 63-67.

Wehrtmann, I. \& Báez, P., 1997. Larvas y estadíos tempranos de desarrollo de crustáceos decápodos de Chile: descripciones publicadas. Investigaciones Marinas, Valparaíso, 25, 263-276.

Williamson, D.I., 1960. Larval stages of Pasiphaea sivado and some other Pasiphaeidae (Decapoda). Crustaceana, 1, 331-341.

Williamson, D.I., 1968. Names of larvae in the Decapoda and Euphausiacea. Crustaceana, 16, 210-213.

Williamson, D.I., 1982. Larval morphology and diversity. In The biology of Crustacea, vol. 2 (ed. D.E. Bliss), pp. 43-110.

Submitted 14 September 1999. Accepted 6 January 2000. 